\title{
Martin Steiner
}

\section{Ke Komenského představám o politice}

Politickým konsekvencím názorů Jana Amose Komenského na politiku a jeho praktickým krokům zejména na poli politiky zahraniční, jak jsme zvyklí říkat dnes, se věnovala řada historiků, bez nároku na úplnost jmenuji alespoň Josefa Polišenského, Josefa Válku, Jaroslava Pánka a Vladimíra Urbánka. Tentokrát bych chtěl obrátit pozornost $\mathrm{k}$ vybraným aspektům jeho myšlení o politice, konkrétně jak Komenský zapojil politiku do svých všenápravných konceptů. Vycházím proto z vybraných pasáží Obecné porady o nápravě věcí lidských (v orig. De rerum humanarum emendatione consultatio catholica, Praha, Academia 1966)

Úvodem ještě, co jsou u Komenského res humanae - věci lidské. Tady Komenský nechává stranou všechno to, co máme společného $\mathrm{s}$ ostatním stvořením a obrací se k tomu vybavení, jež máme oproti ostatním, zejména živočichům, jaksi navíc. To souvisí s lidskou duší, s jejími třemi schopnostmi:

1. rozum, intelekt, s nímž je spojena touha po pravdě, po jejím poznání,

2. vi̊le, která touží po dobru, a

3. moc nad věcmi, jejich tvoření či přetváření a s tím spojené potěšení z takové schopnosti tvořit, konat a jednat.

Z touhy po poznání vzniká filosofie (philosophia), touha po dobru vede ke vzniku náboženství (religio) a touha po jednání ústí v politice (politia). Tak dochází Komenský k triádě věcí lidských, které pro své pokažení potřebují univerzální nápravu. (Panegersia, kap. IV; Consultatio I, sl. 28n.) 
Komenský používá i výrazu politica, avšak rozlišuje: politica je ars, tedy dovednost ve společnosti komunikovat a řídit ji, politia je status, tedy řekněme nastavení vztahů ve společnosti, sama praktická komunikace a řízení společnosti. (Panorthosia, kap. XII; Consultatio II, sl. 509.)

Jak zdůvodňuje Komenský pokaženost politiky: Kdo je povolán k tomu, aby $\mathrm{v}$ politice zaujímal nějaké vedoucí postavení, měl by bezpodmínečně umět ovládat především sám sebe, bez toho není schopen vést, řídit druhé lidi. Základním předpokladem lidského štěstí, spokojenosti a řádu ve společnosti tedy je, aby jí vládli lidé, kteř́ jsou schopni moudře ovládat sami sebe. Neumí-li to, nechtějí-li to, výsledkem je zkáza. Vrchnosti jsou dány od Boha, a to $\mathrm{k}$ vzájemnému prospěchu svému $\mathrm{i}$ poddaných. Obě strany si mají vzájemně sloužit; pokud tomu tak není, jde o pokažený stav, který potřebuje nápravu. (Panegersia, kap. V, 28; Consultatio I, sl. 44nn.)

Cestou k nápravě je politia catholica (universalis). Bude sice nová, avšak utvořená $\mathrm{k}$ obrazu vztahů před pádem části andělů a člověka $\mathrm{v}$ ráji; tyto vztahy se stále udržují v hierarchii andělů, kteří od Boha neodpadli. Tak jako v didaktických spisech a v ostatních pojednáních o univerzální nápravě vytyčuje Komenský i zde cíle, prostředky k jejich dosažení a postupy.

Cílem je svornost mezi národy světa, odstranění válek a jejich prŕičin. Vycházet se přitom má z lidské zkušenosti ověřené rozumem, smyslovým poznáním a Božím zjevením - bez zřetele $\mathrm{k}$ těmto třem zdrojům poznání nemůže politik nic rozhodovat; v tom můžeme vidět soustavné propojování všech těch výše uvedených tř́i lidských věcí, jak se s ním průběžně setkáváme v celé Obecné poradě. Cílová rovnováha svobodných vztahů mezi lidmi je zakotvena v zásadě co chcěs/nechceš, aby druzi činili tobě, čiň/nečin ty jim. Prostředky, jak je u Komenského zvykem, jsou zase trojí:

1. živé, stálé a jasné př́íklady řádného jednání ve společnosti;

2. jednoznačné, srozumitelné a stručné zákony;

3. důsledné trvání na stanovených pravidlech. 
Postupy, způsoby uplatňování nové politiky, shrnuje Komenský opět do tří oblastí:

1. zajištění všech prostředků k míru a klidnému životu;

2. řád $v$ hierarchii, stálá péče a dozor nadřízených nad podřizenými za pomoci veřejných i tajných dozorců - nejvýhodnější by bylo, kdyby každý člen společnosti měl nějaké postavení, funkci, aby se co nejvíce provázala nadřízenost a podřízenost a lidé by si vzájemně pokud možno všichni byli dohlížiteli: v tom spatřuje Komenský jednu ze záruk řádu a spravedlnosti;

3. vše podnikat $\mathrm{v}$ pravdě a poctivě, nikoliv rozvažováním, nýbrž jednáním, konáním.

Ve vládním zřízení by se měly uplatnit lepší a osvědčené prvky všech tří typů, monarchie, aristokracie a demokracie. Budoucí uspořádání tedy bude monarchistické $\mathrm{v}$ tom, že Kristus bude vládcem králů, biskupů i filosofů (univerzální náprava je spojena $\mathrm{s}$ milenarismem, tedy $\mathrm{s}$ očekávaným Kristovým kralováním), aristokratické proto, že všude budou předáky ti nejlepší, a demokratické v tom, že každý bez výjimky bude muset být ve svém domě a ve svém svědomí králem, knězem a učitelem sobě a svým blízkým.

Této nové univerzální politice je třeba se učit od Boha, s pomocí zdravého rozumu a od příkladů $\mathrm{v}$ přírodě; $\mathrm{v}$ žádném případě od zchytralých lidí, jakými jsou např. macchiavellisté. (Panorthosia, kap. XII; Consultatio II, sl. 508nn.)

Nejsa filosof ani politolog nechci vynášet žádné obecně platné soudy o představách Jana Amose, jak uspořádat politiku, život společnosti. Ani nemíním rozhodnout, zda k politice prristupuje jako filosof, nebo spíše jako teolog; on sám by patrně dal přednost tomu druhému; kloním se k tomu také, ale to je vše, nechci to pokládat za jedině platné stanovisko. Na druhé straně snad lze říci, že jeho přístup plyne z přesvědčení, že každý lidský jedinec je ,zoon politikon“, i když to tak alespoň ve sledovaných partiích Obecné porady doslova neříká, tedy i filosof a $\mathrm{v}$ Komenského prrípadě $\mathrm{i}$ 
teolog. Ostatně jeho důraz na lidskou aktivitu je řadou badatelů dokládán a zdůrazňován (např. Dagmar Čapková). Podle mého názoru trpí také Komenského představy o ideálním uspořádání společnosti určitou nekonsistentností - snad je to trochu patrno i z tohoto stručného přehledu. Pro celý Komenského koncept univerzální nápravy, a tudíž i pro jeho představy o politice platí, že jsou neseny vedle humanistického étosu také rysy utopickými. K těm patří zejména přesvědčení, že lze lidskou společnost harmonizovat, že lze ke všem věcem a vztahům najít pravdu, o níž už nebude možno pochybovat; konkrétně v politice pak sladit zájmy jednotlivců i skupin tak, aby se nedostávaly do konfliktů. Jeho argumenty, přesvědčující čtenáře, že s pomocí Boží je to možné, snadné a nutné, znějí dobře a do značné míry přesvědčivě, ale praxe je nepotvrzuje. 